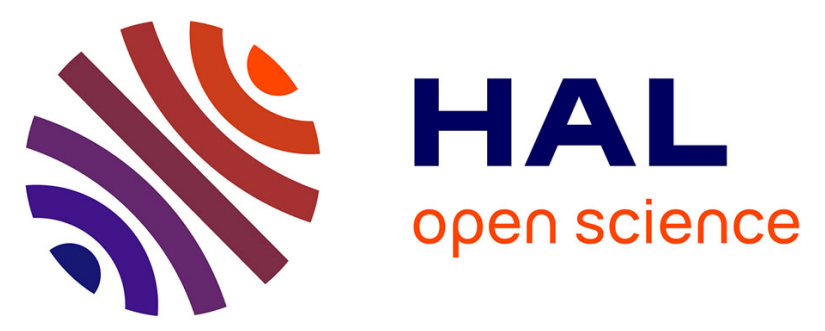

\title{
XRD and electrochemical investigation of particle size effects in platinum-cobalt cathode electrocatalysts for oxygen reduction
}

\author{
I.N. Leontyev, V.E. Guterman, E.B. Pakhoova, P.E. Timoshenko, A.V. \\ Guterman, I.N. Zakarchenko, G.P. Petin, B. Dkhil
}

\section{To cite this version:}

I.N. Leontyev, V.E. Guterman, E.B. Pakhoova, P.E. Timoshenko, A.V. Guterman, et al.. XRD and electrochemical investigation of particle size effects in platinum-cobalt cathode electrocatalysts for oxygen reduction. Journal of Alloys and Compounds, 2010, 500, pp.241-246. 10.1016/j.jallcom.2010.04.018 . hal-00578894

\section{HAL Id: hal-00578894 \\ https://hal.science/hal-00578894}

Submitted on 22 Mar 2011

HAL is a multi-disciplinary open access archive for the deposit and dissemination of scientific research documents, whether they are published or not. The documents may come from teaching and research institutions in France or abroad, or from public or private research centers.
L'archive ouverte pluridisciplinaire HAL, est destinée au dépôt et à la diffusion de documents scientifiques de niveau recherche, publiés ou non, émanant des établissements d'enseignement et de recherche français ou étrangers, des laboratoires publics ou privés. 


\title{
XRD and electrochemical investigation of particle size effects in platinum-cobalt cathode electrocatalysts for oxygen reduction
}

\author{
I.N. Leontyev, ${ }^{*[a, b]}$ V.E. Guterman, ${ }^{[b]}$ E.B. Pakhomova, ${ }^{[b]}$ P.E. Timoshenko, ${ }^{[b]}$ \\ A.V.Guterman, ${ }^{[b]}$ I.N. Zakharchenko, ${ }^{[b]}$ G.P. Petin ${ }^{[b]}$, B.Dkhil ${ }^{[a\}}$
}

$\mathrm{Pt}-\mathrm{Co} / \mathrm{C}$ electrocatalysts with $\mathrm{Pt}$ loadings near $30 \mathrm{wt}$ \% prepared by the impregnation method in water - ethylene glycol solutions were investigated by X-ray diffraction and correlated with electrochemical measurements. We show that the composition of the binary solvent controls the average particle size and its distribution. The unit cell parameter of the $\mathrm{Pt}_{3} \mathrm{Co}$ alloy decreases nonlinearly with decreasing particle size. The ORR activity of the prepared $\mathrm{Pt}-\mathrm{Co} / \mathrm{C}$ catalysts in

\section{Introduction}

Proton-exchange membrane fuel cells (PEMFC) have received considerable attention as promising devices for portable and transport applications, due to their high energy density, relatively low operating temperature and minimal corrosion problems. Yet, the commercial viability of the PEMFC's has been still hindered by several problems including the high cost, insufficient stability against degradation, and agglomeration of the Pt nanoparticles. The latter two phenomena are especially intrinsic to the oxygen electrode. They reduce the catalyst's effective surface and hence the activity. The search for more active, cost-effective, and corrosion stable electrocatalysts for the oxygen reduction reaction (ORR) is therefore a priority in fuel cell catalysis research. The most popular strategy toward more active and stable ORR electrocatalysts has been alloying pure Pt with transition metals, such as $\mathrm{Co}, \mathrm{Ni}$, etc. It has been suggested ${ }^{[1-6]}$ that the activating effect of the alloying elements for the ORR could be associated with (i) modified composition of the surface oxides and improved corrosion resistance of the alloy; (ii) formation of a new electronic structure of the metal; (iii) shortening of the Pt-Pt distance which favors adsorption of oxygen molecules, (iv) formation of a thin $\mathrm{Pt}$ shell at the surface of the nanoparticles due to selective dissolution of a second alloying element, and (v) some other effects. One or another mechanism may prevail depending on specific alloy composition and conditions of the reaction process. The positive effect of the second alloying component on the catalyst's aggregation stability seems to result from strengthening of the nanoparticle to carbon carrier adhesion and/or improved corrosion resistance of the carbon surface regions adjacent to the metal nanoparticles ${ }^{[1,7]}$. Unfortunately, the second component in such alloys is not as stable as $\mathrm{Pt}$, and the alloy composition may alter owing to corrosion during operation of an electrocatalyst ${ }^{[3,5]}$ The corrosion effect on the composition and structure of Pt-Me/C catalysts as well as the dependence of the catalyst's stability on
$\mathrm{H}_{2} \mathrm{SO}_{4}$ solution enhances with decreasing particle size and unit cell parameter as well as with narrowing of the particle size distribution. Corrosion treatment of the synthesized $\mathrm{Pt}-\mathrm{Co} / \mathrm{C}$ materials causes an increase of ca. $1 \mathrm{~nm}$ in average particles size accompanied by broadening of the particle size distribution and decreasing Co content in the Pt-Co alloy. All of the synthesized Pt-Co/C materials show higher ORR activities than do the commercial Pt/C electrocatalysts.

their original composition and structure are therefore subjects of great importance.

In reality, carbon carries the nanoparticles of different size, and its metal coverage itself is variable and not always uniform ${ }^{[1,4,8,9]}$. Optimum size range of the metal nanoparticles is altogether uncertain and is apparently dependent on a particular electrochemical system, conditions of the reaction process, and the alloy composition. The above considerations demonstrate that control over composition and size of the metal alloy nanoparticles is a real challenge both in science and technology.

The purposes of this work are: (i) to study the influence of water - ethylene glycol solvent composition on structural and micro structural parameters of the $\mathrm{Pt}_{3} \mathrm{Co} / \mathrm{C}$ materials prepared by wet synthesis; (ii) to investigate the particle size effect in the synthesized $\mathrm{Pt}_{3} \mathrm{Co} / \mathrm{C}$ electrocatalists by means of $\mathrm{XRD}$, and (iii) to estimate corrosion stability of the synthesized materials in $1 \mathrm{M}$ $\mathrm{H}_{2} \mathrm{SO}_{4}$ solution as well as their ORR activity.

\section{Results and Discussion}

The XRD patterns of all our $\mathrm{Pt}-\mathrm{Co} / \mathrm{C}$ samples, both asprepared and treated in boiling $\mathrm{H}_{2} \mathrm{SO}_{4}$, are presented in Figures 1

[a] I.N. Leontyev, B.Dkhil

Laboratoire Structures, Proprietes et Modelisation des Solides Institution Ecole Centrale Paris

CNRS-UMR8580, Grande Voie des Vignes, 92295 Chatenay-

Malabry Cedex, France

Fax: +33 (0)141131010

E-mail: i.leontiev@rambler.ru

[b] I.N. Leontyev, V.E. Guterman, E.B. Pakhomova, P.E. Timoshenko, A.V.Guterman, I.N. Zakharchenko, G.P. Petin

Department of Chemistry

Southern Federal University

Zorge 5, Rostov-on-Don 344090, Russia

and 2. One can see the pronounced peaks characteristic of a Pt- 
Co alloy with the fcc structure. No obvious peaks indicating the presence of free Co or its oxides are found (see Figures 1,2).

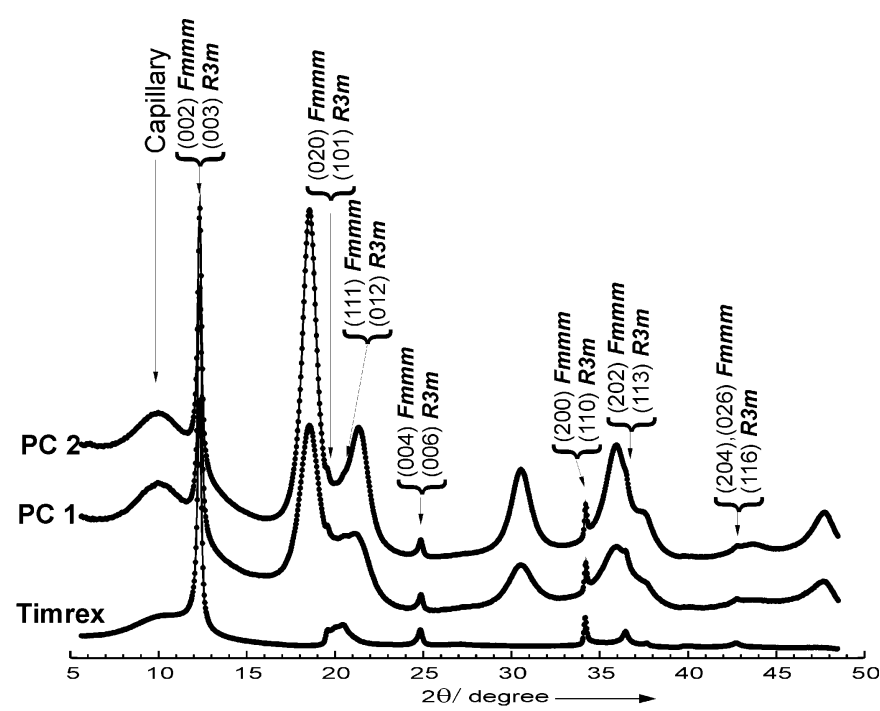

Figure 1. XRD patterns of the carbon-supported $\mathrm{Pt}-\mathrm{Co} / \mathrm{C}$ catalysts (samples PC1, PC2) and of the carbon support itself (Timrex HSAG-300).

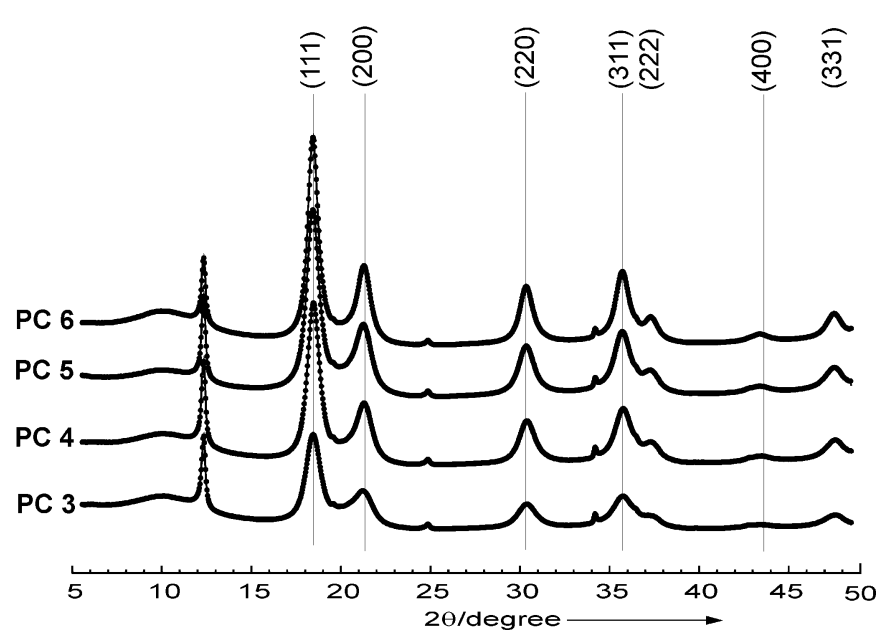

Figure 2. XRD patterns of the carbon-supported $\mathrm{Pt}-\mathrm{Co} / \mathrm{C}$ catalysts (samples PC3-PC6)

The peak shapes were described using the pseudo-Voigt function $^{[10]}$. The X-ray reflections were fitted using the Winplotr from the FullProf software ${ }^{[11]}$. The quality of the fit is shown in Figure 3. It should be noted that our fitting of the reflections from the synthesized samples was made with allowance for reflections from the carbon support. The neglect of this contribution can lead to erroneous determination of the Bragg angle $2 \theta$ and the full width at half maximum (FWHM), hence underestimation of the particle size (our estimated error is about $0.2 \mathrm{~nm}$ for particle sizes close to $3 \mathrm{~nm}$ ). XRD-pattern of the carbon carrier (Timrex HSAG$300)$ representing a mixture of the rhombohedral $R 3 m(a=3.6420$ $\left.\AA, \alpha=39^{\circ} 30\right)$ and orthorhombic Fmmm $(a=2.456 \AA$, $b=4.254 \AA$, $c=6.696 \AA$ ) graphite phases is shown in Figure 1 .

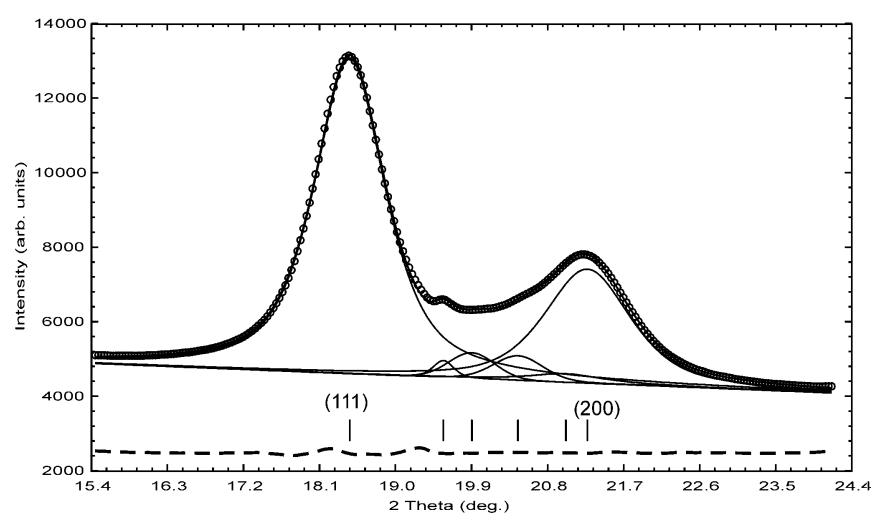

Figure 3. Quality of fit for the observed 111 and 200 reflections (open circles), fitted data (solid curve) and the difference (dashed curve).

Examination of the FWHM values for all the samples revealed the occurrence of anisotropic line broadening. Figure.4 shows the FWHM values at different $2 \theta$ 's for the as-prepared (PC5) and treated (PC6) samples where the anisotropy is most pronounced.

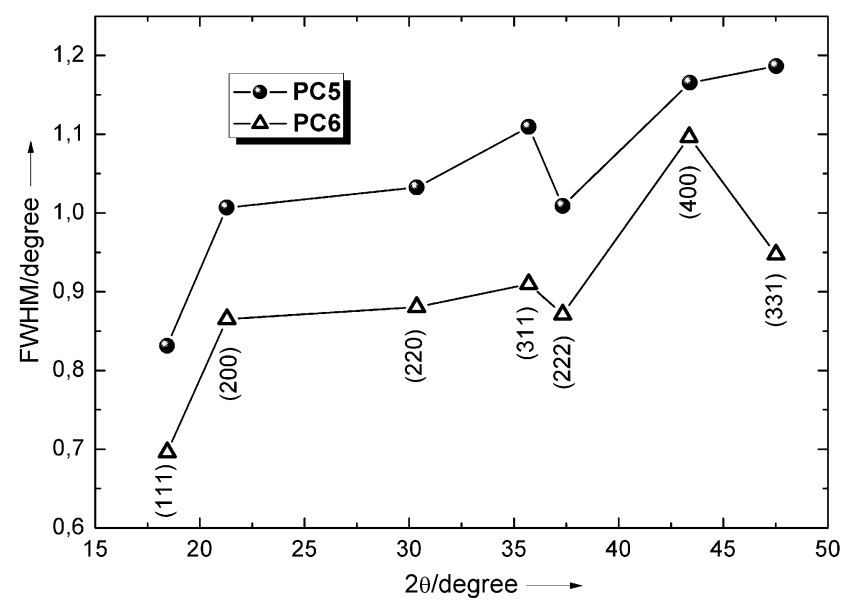

Figure 4. FWHM values vs. $2 \theta$ for the as-prepared (PC5) and treated (PC6) samples of $\mathrm{Pt}-\mathrm{Co} / \mathrm{C}$ catalyst.

The (111) reflection has consistently lower FWHM's compared to the other reflections, and the anisotropy increases with increasing particle size. In general, the anisotropic line broadening may be attributed to the three factors: the presence of stacking faults, the presence of dislocations, and nonequivalence of the particle sizes along different crystallographic directions. In our case, it is due to the particle size anisotropy. The presence of stacking faults would provoke a reduced coherent scattering region along the $<111>$ direction (as compared to those for other directions) hence a higher FWHM value. The occurrence of dislocations is hardly probable. It was shown ${ }^{[12,13]}$ that the particles became dislocation-free below a certain critical size. For instance, dislocation-free particles of iron and nickel have diameters of 23 and $140 \mathrm{~nm}$, respectively ${ }^{[12]}$. The same is evident from the high-resolution TEM images of $\mathrm{Pt}_{3} \mathrm{Co}$ and $\mathrm{Pt}_{69} \mathrm{Ni}_{31}$ particles $^{[3,7]}$.

The average particle size was determined by three separate techniques. The first was the so-called "double Voigt" method ${ }^{[14]}$. The main relations in this method are 


$$
\beta_{L}=\beta_{L S}+\beta_{L D} \frac{s^{2}}{s_{0}^{2}}, \beta_{G}^{2}=\beta_{G S}^{2}+\beta_{G S}^{2} \frac{s^{2}}{s_{0}^{2}},
$$

where $\mathrm{s}=2 \sin \theta / \lambda=1 / \mathrm{d}, \beta_{L}, \beta_{G}$ are the integral breadths of the Lorentz and Gauss functions, and $\beta_{L S}, \beta_{G S}, \beta_{L D}, \beta_{G D}$ are the integral breadths of the Lorentz (L) and Gauss (G) functions, corresponding to the size (S) and strain (D) broadening, respectively.

For a Voigt size-broadened profile, the size coefficient is given as the Fourier transform $\mathrm{A}_{\mathrm{S}}(\mathrm{L})=\exp \left(-2 \mathrm{~L} \beta_{\mathrm{LS}}-\pi \mathrm{L}^{2} \beta_{\mathrm{GS}}^{2}\right)$, where $L=n\left|a_{3}\right|$ is the length of columns of cells along the $a_{3}$ direction normal to the diffracting planes. The second derivative of the size coefficient, $\frac{d^{2} \mathrm{~A}(\mathrm{~L})}{d \mathrm{~L}^{2}}=\left[\left(2 \pi \mathrm{L} \beta_{\mathrm{GS}}^{2}+2 \beta_{\mathrm{LS}}\right)^{2}-2 \pi \beta_{\mathrm{GS}}^{2}\right] \mathrm{A}_{\mathrm{S}}(\mathrm{L})$, defines the size distribution function $\quad \mathrm{p}_{\mathrm{v}}(\mathrm{L}) \propto \mathrm{L} \frac{d^{2} \mathrm{~A}(\mathrm{~L})}{d \mathrm{~L}^{2}}$. The respective mean values for the volume-weighted grain size are given as

$$
\overline{\mathrm{D}}_{\mathrm{v}}=\frac{\int_{0}^{\infty} \mathrm{Lp} \mathrm{p}_{\mathrm{v}}(\mathrm{L}) \mathrm{dL}}{\int_{0}^{\infty} \mathrm{p}_{\mathrm{v}}(\mathrm{L}) \mathrm{dL}}=\frac{\exp \left(\mathrm{k}_{\mathrm{S}}^{2}\right)}{\beta_{\mathrm{GS}}} \operatorname{erfc}\left(\mathrm{k}_{\mathrm{s}}\right), \text { where } \mathrm{k}_{\mathrm{S}}=\beta_{\mathrm{LS}} /\left(\sqrt{\pi} \beta_{\mathrm{GS}}\right)
$$

Determination of the volume-weighted grain size was carried out by means of the D. Balzars program BREADTH ${ }^{[15]}$.

The second method is based on the assumption that the grain size distribution GSD obeys a Gamma function

$$
G S D\left(\mathrm{D}: \mathrm{D}_{0}, \mathrm{~m}\right)=\frac{\mathrm{D}_{0}^{-\mathrm{m}-1}}{\Gamma(\mathrm{m}+1)} \mathrm{D}^{\mathrm{m}} \mathrm{e}^{-\mathrm{D} / \mathrm{D}_{0}},
$$

where $D_{0}=\sigma^{2} / \overline{\mathrm{D}}, \mathrm{m}=(\overline{\mathrm{D}} / \sigma)^{2}-1$, which is very close to the conventional lognormal distribution. A detailed description and justification of this method, called the $F W \frac{1}{5} / \frac{4}{5} M$ one, can be found in Ref. ${ }^{[16]}$. The basic idea is as follows: The average particle size $\bar{D}$ and its dispersion $\sigma$ were derived from the expressions

$$
\bar{D}=2 \mathrm{BC} / \mathrm{FW} \frac{4}{5} \mathrm{M}, \sigma=2 \mathrm{~B} \sqrt{\mathrm{C}} / \mathrm{FW} \frac{4}{5} \mathrm{M} .
$$

The coefficients $B$ and $C$ were found from the expressions

$$
\begin{gathered}
\mathrm{A}=\operatorname{arcctg}\left(277069-105723 \mathrm{FW} \frac{1}{5} \mathrm{M} / \mathrm{FW} \frac{4}{5} \mathrm{M}\right), \\
\mathrm{B}=0.001555+0.00884 \times \operatorname{ctg}(0.002237-2101 \times \mathrm{A}), \\
\mathrm{C}=-0.6515-463695 \times \mathrm{A},
\end{gathered}
$$

where $F W 1 / 5 M$ и $F W 4 / 5 M$ are the full widths at $1 / 5$ and $4 / 5$ of the peak maximum, respectively. As was shown in Ref. ${ }^{[17]}$, the grain size distribution determined by this method for strain-free samples is in good agreement with that found from the SEM analysis. For GSD determination by this method we have developed the L\&TGSD program ${ }^{[18]}$

The third way applied here for determination of the average particle size is based on the well-known Scherrer equation $\bar{D}=\mathrm{K} \lambda /\left(\mathrm{H}_{\mathrm{pv}} \cos \theta\right)^{[19]}$, where $\lambda$ is the wavelength; $\bar{D}$ - the volume averaged particle size; $\theta$ - the Bragg angle, and $K=0.89$ the Sherrer constant.

The fitting results for the (111) peak were employed for estimation of the average particle size and GSD parameters using the Sherrer equation and the $F W \frac{1}{5} / \frac{4}{5} M$ method. The (111) and (222) peaks were used for the «double-Voight» method.

Values of the average particle size along the (111) direction, $\bar{D}_{111}$, for the synthesized Pt-Co/C samples estimated using the «double-Voight», the $F W \frac{1}{5} / \frac{4}{5} M$, and the Sherrer methods are listed in Table 1.

Table 1. Average particle size, unit cell parameter a, Pt-Pt distance, and alloy composition of the nanostructured $\mathrm{Pt}-\mathrm{Co} / \mathrm{C}$ electrocatalysts.

\section{Average particle size}

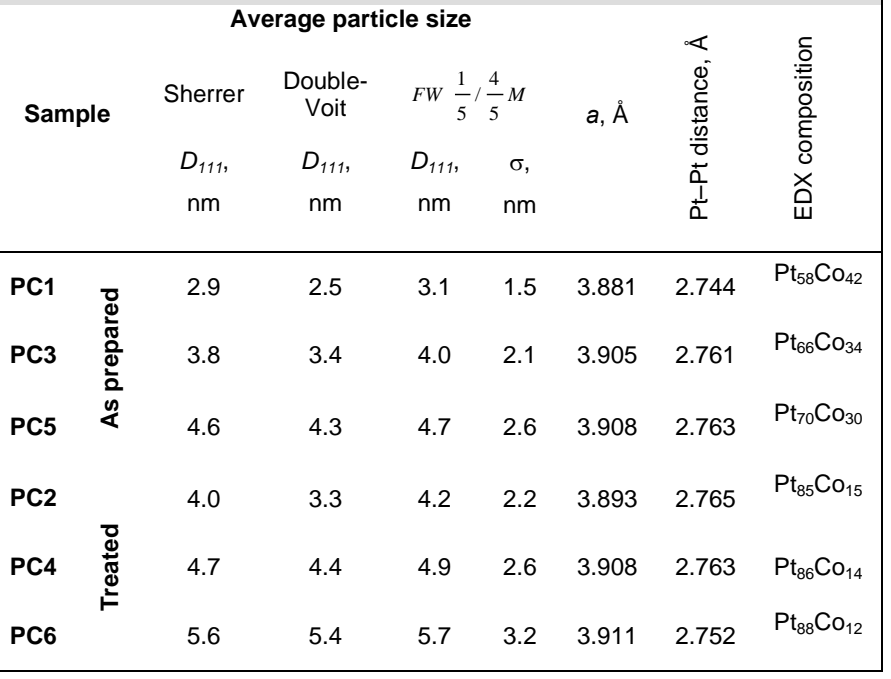

As follows from Table 1, despite a discrepancy in the particle size values for each individual sample, all the three techniques yield nearly identical variation of the dimension of the as-prepared $\mathrm{Pt}-\mathrm{Co}$ nanoparticles as a function of ethylene glycol concentration in the solvent, and very similar changes subsequent to the treatment. Thus, the average particle size increases in the sequence $\mathrm{PC} 1>\mathrm{PC} 3>\mathrm{PC} 5$ with lowering concentrations of the organic component in the solvent, and the treatment with $\mathrm{H}_{2} \mathrm{SO}_{4}$ brings about an additional increase of ca. 0.8-1 nm.

Grain size distributions calculated by means of the $F W \frac{1}{5} / \frac{4}{5} M$ and "double Voigt" methods are presented at Figure 5 for the as-prepared (PC5) and treated (PC6) samples. Since the "double Voigt" method, unlike the $F W \frac{1}{5} / \frac{4}{5} M$ one and Sherrer equation, takes into account the microstrains, and the two results still coincide very closely, it may be concluded that a contribution of the strains to the observed line broadening is 

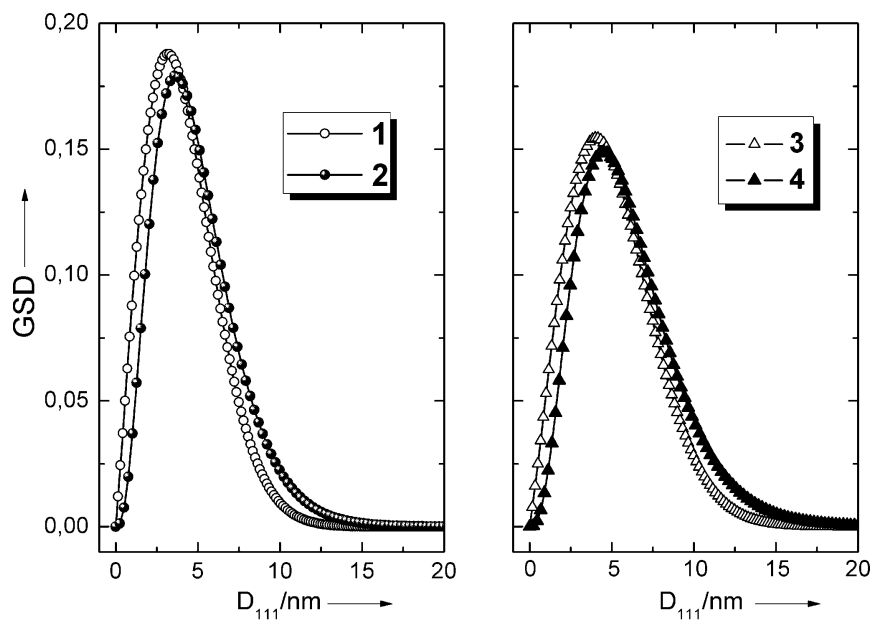

Figure 5. Comparison of grain size distributions calculated by means of the "double Voigt" (curves 1, 3) and $F W \frac{1}{5} / \frac{4}{5} M$ (curves 2, 4) methods for the asprepared PC5 (left panel) and treated PC6 (right panel) samples of the Pt-Co/C catalyst.
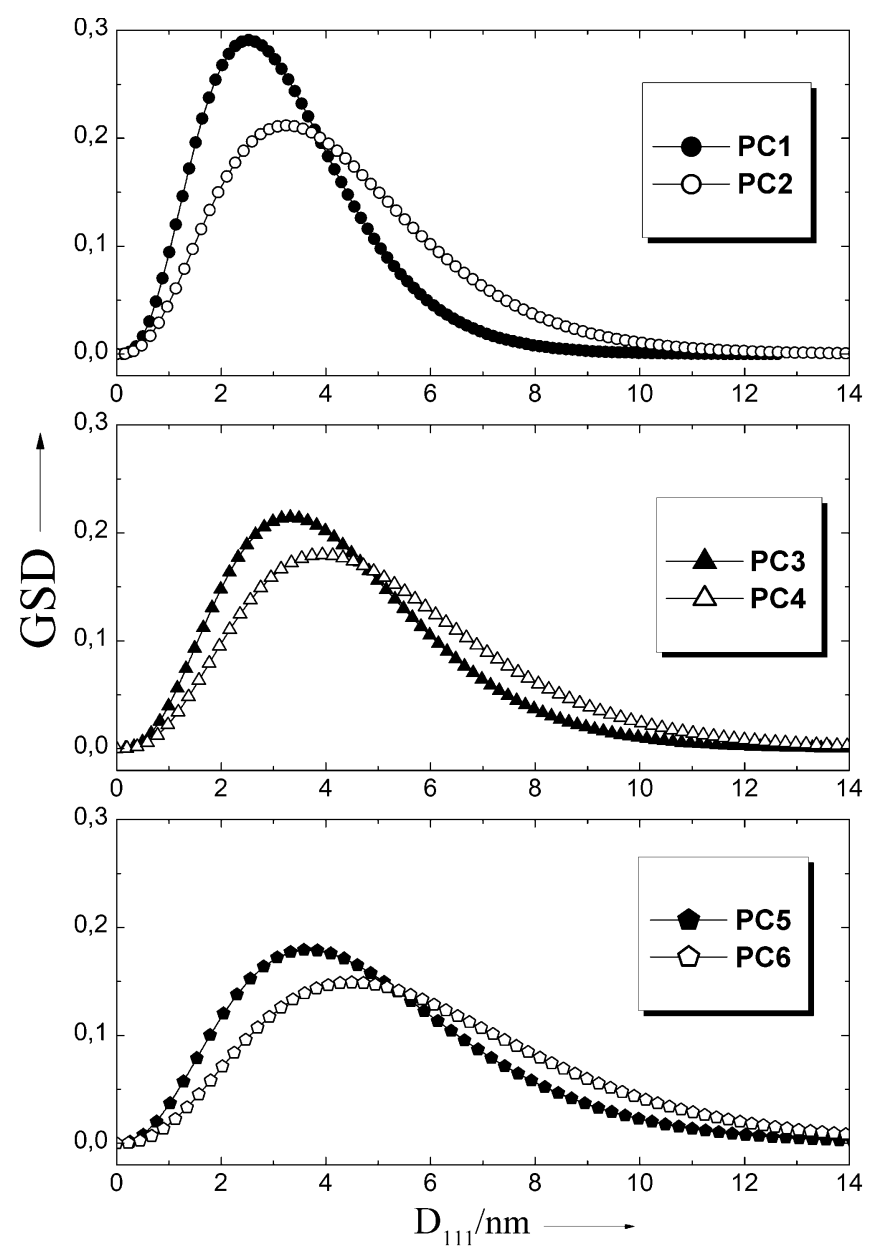

Figure 6. Grain size distributions as determined by the $F W \frac{1}{5} / \frac{4}{5} M$ method. insignificant, and the Sherrer equation and the $F W \frac{1}{5} / \frac{4}{5} M$ method are applicable for definition of the average particle size and the GSD parameters. Figure 6 shows grain size distributions calculated by the $F W \frac{1}{5} / \frac{4}{5} M$ method for all three pairs of the asprepared and treated $\mathrm{Pt}-\mathrm{Co} / \mathrm{C}$ samples. The narrowest GSD is found for a 1:5 ratio of water to the nonaqueous component of the solvent. This means that, during synthesis of that material (PC1) the nucleation to growth activation energy ratio $E_{\text {nucl }} / E_{g r}$ was the lowest. In such conditions, the nucleation process prevails over growth of the particles, which corresponds to the instantaneous nucleation model. As the ratio $E_{n u c} / E_{g r}$ increases with increasing water content (samples PC3, PC5), the growth process becomes more favorable, leading to a larger particle size and GSD broadening (Figure 6).

From comparison of the unit-cell parameters (Table 1) and their dependence on the particle size $\overline{\mathrm{D}}_{111}$ (Fig.7), the following conclusions could be made. (i) The parameters $a$ in all of the synthesized materials are lower than that of pure Pt, $\left(a_{P t}=3.9231 \AA\right.$ ${ }^{[20]}$ ). This fact confirms the formation of a Pt-Co solid solution. (ii) A nonlinear dependence of the unit cell parameter $a$ on $\bar{D}_{111}$ is observed for the treated samples which have practically identical compositions (within the experimental error). This phenomenon could be explained by a size effect which is due to uncompensated interatomic distances and reduced interplanar spacing near the particle surface. This results in compression of the particles and reduction of the unit cell parameter ${ }^{[21]}$. The size effect should be more pronounced for smaller nanoparticles where concentration of the surface atoms is essentially higher. A similar effect was observed for nanoparticles of $\mathrm{Pd}^{[22]}$ and $\mathrm{Ag}^{[23]}$.

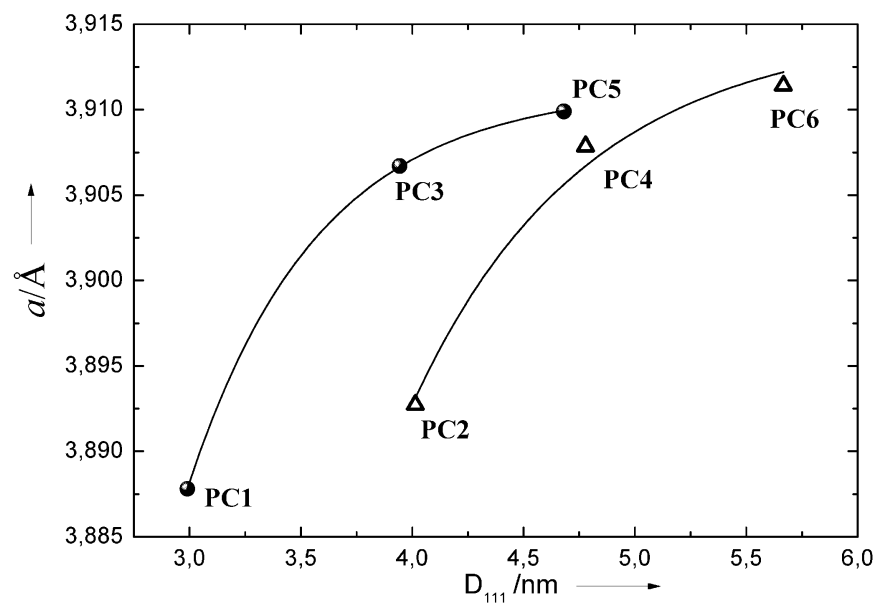

Figure 7. Unit cell parameter $a$ as a function of the particle size $D_{111}$ along the $<111>$ direction.

A nonlinear dependence of the unit cell parameter on the average particle size observed for the as-prepared samples is a consequence of both the aforesaid size effect and different Co concentrations in the crystallites. (iii) Samples labeled PC4 (the treated PC3) and PC5, although differ essentially in composition, have practically identical unit-cell parameters and particle sizes. It therefore seems that a fraction of Co atoms in the starting (asprepared) samples were not included in the Pt-Co alloy crystallites but were present in an amorphous phase. A similar 
assumption, concerned with dissolution of only "amorphous" cobalt atoms during corrosion treatment of $\mathrm{Pt}-\mathrm{Co} / \mathrm{C}$ catalysts was made in Ref. ${ }^{[3]}$.

Cathode chronoamperometric curves for our as-prepared samples demonstrate higher specific currents than those measured for the commercial Pt/C electrocatalysts, TEC10V50E (TKK Co., $46 \% \mathrm{Pt}$ ) or E-TEC (40\% Pt). The expected and actually observed enhancement of the ORR activity in the PC5 $<$ PC3 $<$ PC1 series (Fig.8) may be a result of both the enlargement of the metal surface area and an increase in the intrinsic catalytic activity due to facilitation of dissociative oxygen adsorption through shortening of the $\mathrm{Pt}$ - Pt distances, or the unit cell parameter (Fig. 9)

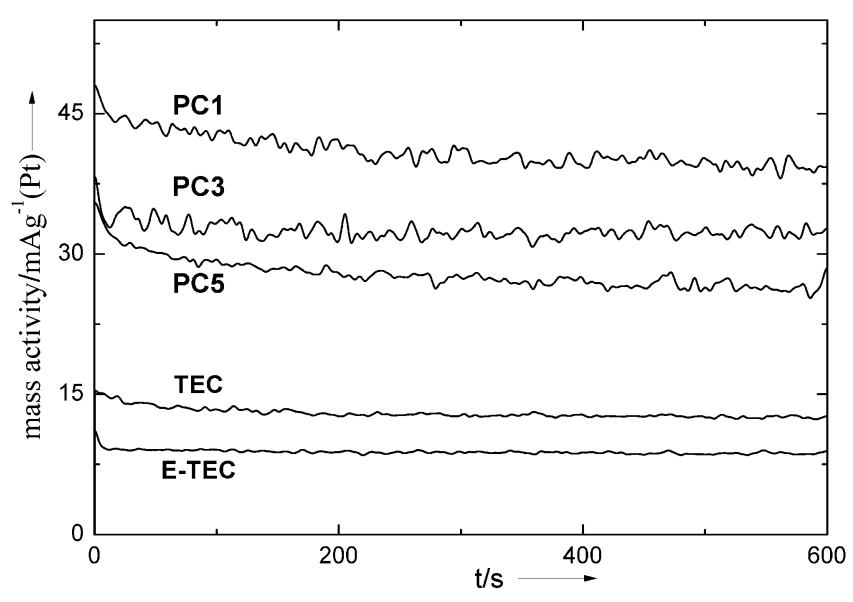

Figure 7. Room-temperature chronoamperograms of the $\mathrm{Pt}-\mathrm{Co} / \mathrm{C}$ catalysts at $0.72 \mathrm{~V}$ in $1 \mathrm{M} \mathrm{H}_{2} \mathrm{SO}_{4}\left(\mathrm{O}_{2}\right.$ atmosphere, rotating disk electrode, $\left.\omega=1000 \mathrm{~min}^{-1}\right)$.

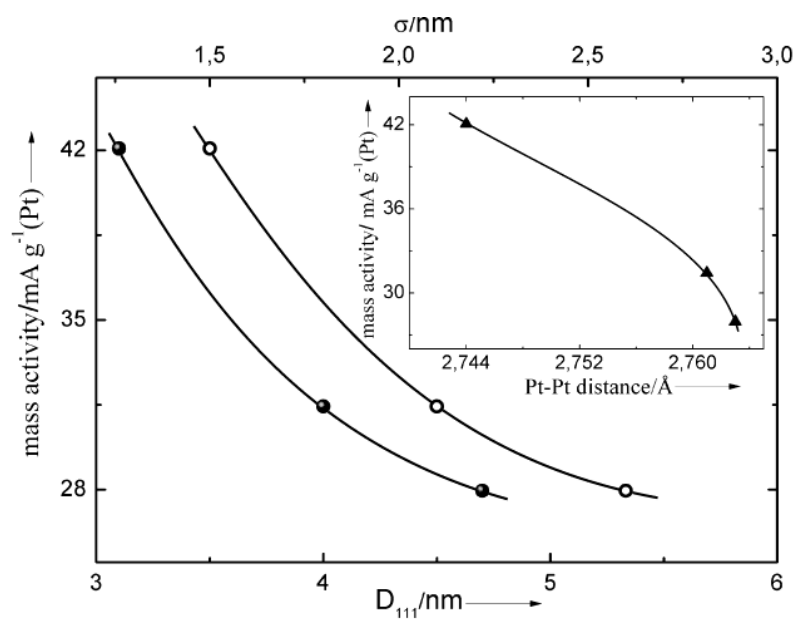

Figure 8. Mass activity of electrocatalysts at $0.72 \mathrm{~V}(\mathrm{t}=200 \mathrm{~s})$ as function of the particle size $D_{111}$ along the $<111>$ direction, GSD dispersion $\sigma$, and $\mathrm{Pt}-\mathrm{Pt}$ distance.

\section{Conclusion}

The $\mathrm{Pt}_{3} \mathrm{Co} / \mathrm{C}$ nanoscale materials with average particle sizes of 2.9-4.6 nm and metal loadings of $24-30 \mathrm{wt} \%$ were prepared by wet synthesis using water - ethylene glycol matrix solution and $\mathrm{NaBH}_{4}$ as a reducing agent. It was found that the average particle size $\langle D\rangle_{111}$ of the synthesized materials decreases progressively with increasing concentration of the organic component (ethylene glycol) in the matrix solution. The GSD dispersion $\sigma$ decreases with decreasing size of the $\mathrm{Pt}_{3} \mathrm{Co}$ nanoparticles (higher ethylene glycol concentrations in the matrix solution). The narrowest GSD is observed for a $\mathrm{H}_{2} \mathrm{O}-\mathrm{EG}$ ratio of 1:5.

The average particle size increases by $0.8-1 \mathrm{~nm}$, and the grain size distribution becomes broader after treating the $\mathrm{Pt}_{3} \mathrm{Co} / \mathrm{C}$ samples with hot $\mathrm{H}_{2} \mathrm{SO}_{4}$ solution.

The unit cell parameter as a function of the particle size shows nonlinear behavior both for the as-prepared samples and those treated with hot $\mathrm{H}_{2} \mathrm{SO}_{4}$ solution during $1 \mathrm{hr}$.

An increase in the anisotropic line broadening with increasing grain size was observed for all of the tested samples. The observed anisotropic line broadening is due to nonequivalent particle sizes along different crystallographic directions.

The mass ORR activity of the prepared $\mathrm{Pt}_{3} \mathrm{Co} / \mathrm{C}$ catalysts in $\mathrm{H}_{2} \mathrm{SO}_{4}$ solutions enhances in the order PC5 < PC3 < PC1 (i.e., with decreasing average particle size, unit cell parameter, and GSD dispersion). All of the as-prepared samples show higher catalytic activities than do the commercial $\mathrm{Pt} / \mathrm{C}$ materials, TEC10V50E (TKK Co., 46\% Pt) and E-TEC (40\% Pt).

\section{Experimental Section}

Preparation of the electrocatalysts. Carbon supported Pt-Co electrocatalysts with nominal Pt:Co atomic ratio of 3:1 were prepared by a low temperature method using sodium borohydride as a reducing agent ${ }^{[24]}$. A high surface area carbon (Timrex HSAG-300) was impregnated with solutions of chloroplatinic acid $\left(\mathrm{H}_{2} \mathrm{PtCl}_{6}{ }^{*} 6 \mathrm{H}_{2} \mathrm{O}\right)$ and cobalt nitrate $\left(\mathrm{Co}\left(\mathrm{NO}_{3}\right)_{2}{ }^{*} 6 \mathrm{H}_{2} \mathrm{O}\right)$. The metals were then reduced at room temperature with a sodium borohydride solution which was slowly added to the carbon dispersion at $p H 10$ under sonication. The water/ethylene glycol mixture was used as a solvent. Water and the nonaqueous component of the solvent were taken in ratios of 1:5, 1:1, and 5:1 for samples labeled PC1, PC3, and PC5, respectively. The resulting material represented 24-30 wt.\% metal on the carbon support. All prepared samples were treated in $1 \mathrm{M} \mathrm{H}_{2} \mathrm{SO}_{4}$ at $100^{\circ} \mathrm{C}$ for $1 \mathrm{hr}$ for estimation of the corrosion and aggregate stabilities. The treated samples then received designations PC2, PC4, and PC6, respectively. Metal loadings in the $\mathrm{Pt}-\mathrm{Co} / \mathrm{C}$ materials were determined by differential thermal analysis using a Diamond TG/DTA derivatograph (Perkin Elmer). The Pt:Co atomic ratios in the synthesized catalysts were ascertained by means of an Energy Dispersive X-ray Spectrometry System DX-95 (EDAX, Inc).

Electrochemical measurements. To test the catalytic activity of the prepared $\mathrm{Pt}_{3} \mathrm{Co} / \mathrm{C}$ materials, the rotating disk electrode (RDE) method was used. The glass-carbon electrode's butt-end was soaked with a drop of the catalyst's alcohol suspension containing a small amount of polyvinilidenefluoride. The RDE was rotated at $1000 \mathrm{rpm}$ and stabilized at $0.72 \mathrm{~V}$ with an IPC-Pro potentiostat during the current measurements. The electrolyte was a $1 \mathrm{M} \mathrm{H}_{2} \mathrm{SO}_{4}$ solution saturated with oxygen $(p=1 \mathrm{~atm})$. The potentials cited in this work are referred to that of the reversible hydrogen electrode.

X-ray diffraction (XRD). Powder diffraction patterns were recorded at the Swiss-Norwegian Beam Lines (SNBL) at the ESRF $(\lambda=0.72287 \AA)$ using a MAR345 image-plate detector. The wavelength, sample-todetector distance $(150 \mathrm{~mm})$ and resolution of the setup were calibrated with $\mathrm{LaB}_{6}$ powder (NIST) ${ }^{[25]}$. The samples were loaded into glass capillaries (Hilgenberg $\mathrm{GmbH}$ ) having a diameter of $0.3 \mathrm{~mm}$ and a wall thickness of $0.01 \mathrm{~mm}$. The data were processed with the Fit2D 
software $^{[26]}$. Corrections for the instrumental broadening were made according to a conventional procedure described, e.g., in Ref. ${ }^{[27]}$.

\section{Acknowledgements}

The authors wish to thank $D$. Chernyshov and V. Dmitriev for valuable cooperation and fruitful discussion of the results. The work was supported by The Southern Federal University (internal grant No. 05/6-114) and the Russian Foundation for Basic Research (grant No. 08-08-00869).

Keywords: platinum alloy $\cdot$ grain size distribution $•$ electrocatalysis $\cdot$ oxygen reduction reaction $(\mathrm{ORR}) \cdot \mathrm{X}$-ray diffraction (XRD)

[1] D. Thompsett, Catalysts for the Proton Exchange Membrane Fuel Cell, in: Handbook of Fuel Cells - Fundamentals, Technology, and Applications. Wiley, New York, 2003 pp. 6-1-6-23.

[2] L. Xiong, A.M. Kannan, A. Manthiram, Electrochem. Commun. 2002, 4 898-903.

[3] N. Travitsky, T. Ripenbein, D. Golodnitsky, Y. Rosenberg, L. Burshtein, E. Peled, J.Power Sources 2006, 161, 782-789.

[4] Hector R. Colon-Mercado, Branko N. Popov, J. Power Sources 2006, 155, 253-263.

[5] E. Antolini, J. R. C. Salgado, E. R. Gonzalez, J. Power Sources 2006 160, 957-968.

[6] E. Antolini, J. R.C. Salgado, E. R. Gonzalez, J. Power Sources 2006 155, 161-166.

[7] Xingwen Yu, Siyu Ye, J. Power Sources 2007, 172, 133-144.

[8] V R. Stamenkovic B. S. Mun, M. Arenz, et al., Nature (London, U. K.) 2007, 6, 241-247.

[9] E. Antolini, J.R.C. Salgado, E.R. Gonzalez, J. Electroanal. Chem. 2005 580, 145-154

[10] P. Thompson, D.E. Cox, J.B. Hastings, J. Appl. Cryst. 1987, 20, 79-83.

[11] T. Roisnel, J. Rodriguez-Carvajal, WinPLOTR: Windows tool for powder diffraction patterns analysis, Materials Science Forum, Proceedings of the Seventh European Powder Diffraction Conference (EPDIC 7), Ed. R. Delhez and E.J. Mittenmeijer, 2000, 118-123.

[12] V.G. Gryaznov, A.M. Karpelov, A.E. Romanov, Technical Physics Letters (Pis'ma v Zhurnal Tekhnicheskoi Fiziki) 1989, 15, 39-43.

[13] V.G. Gryaznov, I.A. Polonsky, A.E. Romanov, L.I. Trusov., Phys. Rev. B: Condens. Matter Mater. Phys. 1991, 44, 42-46.

[14] D.Balzar, H. Ledbetter, J. Appl Cryst. 1993, 26, 97- 103.

[15] D. Balzar, J. Appl Cryst. 1995, 28, 244-245.

[16] R. Pielaszek, J. Alloys and Compounds 2004, 382, 128-132.

[17] A. Vorobiev, D. Chernyshov, G. Gordeev, D. Orlova, J. Appl. Cryst. 2008, 41, 831- 835

[18] http://www.nanotechnology.sfedu.ru/index.php?page=rus.faculty.projects.

[19] H. P. Klug, L. E. Alexander, X-ray Diffraction Procedures from Polycrystalline and Amorphous Materials. Wiley, New York 1974 p. 275.

[20] R. T. Downs, K. L. Bartelmehs, G. V. Gibbs, M. B. Boisen, Am. Mineral. 1993, 78, 1104

[21] W. Huang, R. Sun, J. Tao, L.D. Menard, R. Nuzzo, J.M. Zuo, Nat. Mater. 2008, 7, 308-313.

[22] W. H. Qi, M. P. Wang, Y. C. Su, J. Materials Science Letters 2002, 21 , 877-878.

[23] M. Dubiel , H. Hofmeister, E. Schurig, Phys. Status Solidi B 1997, 203, R5-R6.

[24] V.E. Guterman, S.V. Belenov, O.V. Dymnikova, T. A. Lastovina, Ya. B. Konstantinova, N. V. Prutsakova, Inorganic Materials 2009, 45, i.4 (in press).

[25] Standard Reference Materials, vol. 674, National Institute of Standards and Technology, Gaithersburg, MD, USA, 1983.

[26] A. P. Hammersley, S. O. Svensson, M. Hanfland, A. N. Fitch and D. Häusermann, High Pressure Res. 1996, 14, 235-248.

[27] S. Vives, E. Gaffet, C. Meunier, Materials Science and Engineering 2004 A366, 229-.

Received: ((will be filled in by the editorial staff))

Published online: ((will be filled in by the editorial staff)) 
